\section{To: (Receiving Organization) Distribution}

5. Proj./Prog./Dept./Div.:

Spent Nuclear Fuel Project

8. Originator Remarks:

For approval and information

11. Receiver Remarks:

11A. Design Basel ine Document? [.] Yes

[X] No
3. From: (originating Organization) SNF Characterization Project/ 2T720

6. Design Authority/ Design Agent/Cog. Engr.:

L.A. Lawrence

4. Related EDT No.:

7. Purchase Order No.:

$N / A$

9. Equip./Component No.: $N / A$

10. System/Bldg./Facility: $K$ Basins/100-K

12. Major Assm. Dwg. No.: N/A :

13. Permit/Permit Application No.:

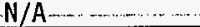

14. Required Response Date: N/A

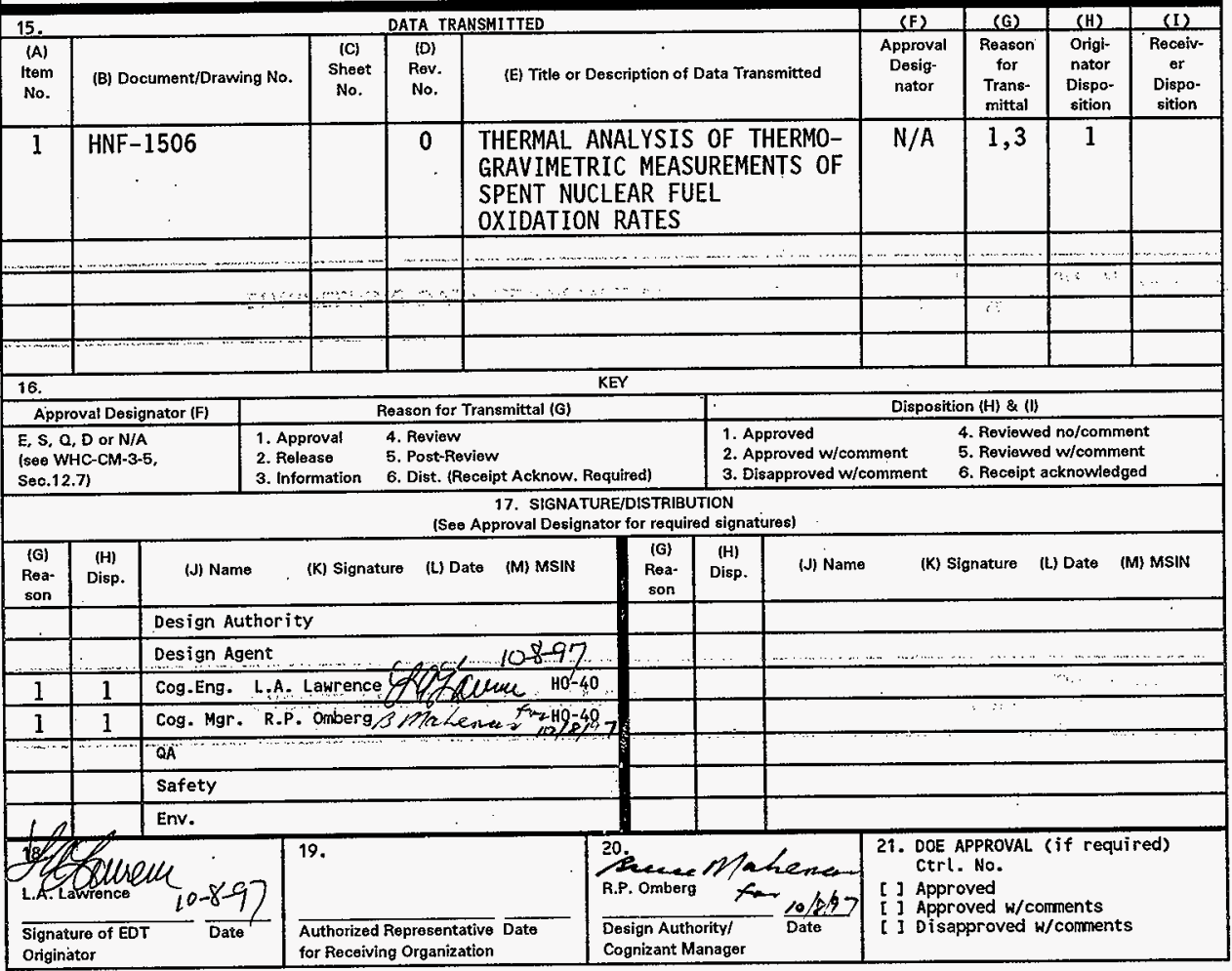




\title{
THERMAL ANALYSIS OF THERMO-GRAVIMETRIC MEASUREMENTS OF SPENT NUCLEAR FUEL OXIDATION RATES
}

\author{
E. R. Cramer
}

Numatec Hanford Company, Richland, WA 99352

\section{J. Abrefah}

Pacific Northwest National Laboratory, Richland, WA 99352

EDT/ECN: 620796 UC: 2070

Org Code: 2T720 Charge Code: LB027

B\&R Code: EW7040000 Total Pages: 49 a 10-8-97

Key Words: Thermal Analysis, Thermo-Gravimetric Analysis Fuel Examinations, 105-K Basins, Spent Nuclear Fuel

Abstract: A detailed thermal analysis was completed of the sample temperatures in the Thermo-Gravimetric Analysis (TGA) system used to measure irradiated $\mathbb{N}$ Reactor fuel oxidation rates. Measured temperatures in the TGA are within approximately $10{ }^{\circ} \mathrm{C}$ of the actual sample temperatures and no adjustments to reported data to account for the heat input from the oxidation process are necessary.

TRADEMARK DISCLAIMER. Reference herein to any specific commercial product, process, or service by trade name, trademark, manufacturer, or otherwise, does not necessarily constitute or inply its endorsement, recomendation, or favoring by the United States Government or any agency thereof or its contractors or subcontractors.

Printed in the United States of America. To obtain copies of this document, contact: Document Control Services, P.O. Box 950, Mailstop H6-08, Richland WA 99352, Phone (509) 372-2420; Fax (509) 376-4989.
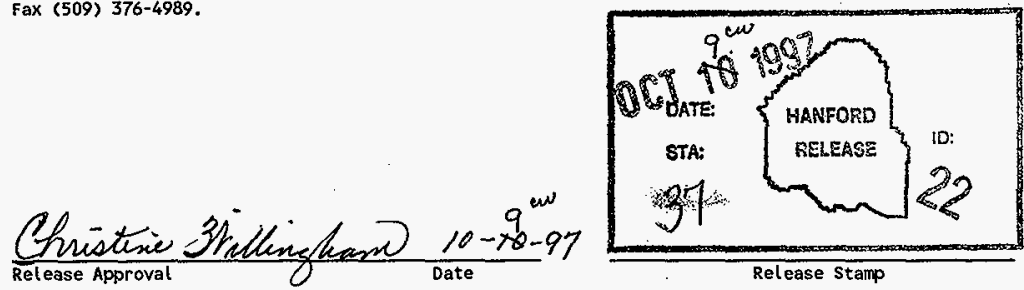

Release Stamp 
HNF-1506, Rev, 0

THERMAL ANALYSIS OF THERMO-GRAVIMETRIC MEASUREMENTS

OF SPENT NUCLEAR FUEL OXIDATION RATES

\author{
E. R. Cramer \\ Numatec Hanford Corporation \\ J. Abrefah \\ Pacific Northwest National Laboratory
}

October 1997 
HNF-1506, Rev. 0

Document Title: THERMAL ANALYSIS OF THERMO-GRAVIMETRIC MEASUREMENTS OF SPENT NUCLEAR FUEL OXIDATION RATES

Prepared by:

Prepared by:

Reviewed by:

Approved by:

Approved by:

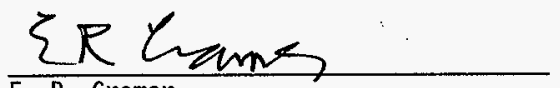

E. R. Cranmer

Numatec Hanford Corporation

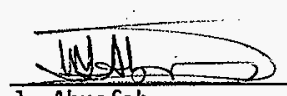

J. Abrefah

Pacific Northwest National Laboratory

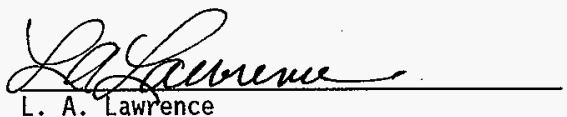

L. A. Lawrence

SNF Characterization Project

Sucre 9 Makers for

R. P. Omberg, Manager (Acting)

SNF Characterization Project

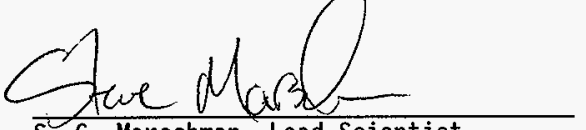

S.C. Marschman, Lead Scientist

Radiomaterials Performance Team Pacific Northwest National Laboratory $\frac{10 / 6 / 97}{\text { Date }}$

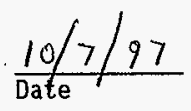

$\frac{10 / 6 / 97}{\text { Date }}$

$\frac{10 / 8 / 97}{\text { Date }}$

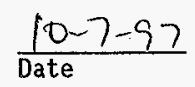

1 
HNF-1506, Rev. 0

This page intentionally left blank. 
HNF-1506, Rev. 0

\section{EXECUTIVE SUMMARY}

A detailed thermal analysis was completed of the sample temperatures in the Thermo-Gravimetric Analysis (TGA) system used to measure irradiated N Reactor fuel oxidation rates. Sample temperatures during the oxidation process did not show the increase which was postulated as a result of the exothermic reactions. The analysis shows the axial conduction of heat in the sample holder effectively removes the added heat and only a very small, i.e., $<10^{\circ} \mathrm{C}$, increase in temperature is calculated. A room temperature evaporation test with water showed the sample thermocouple sensitivity to be more than adequate to account for a temperature change of approximately $5{ }^{\circ} \mathrm{C}$. Therefore, measured temperatures in the TGA are within approximately $10{ }^{\circ} \mathrm{C}$ of the actual sample temperatures and no adjustments to reported data to account for the heat input from the oxidation process are necessary. 
HNF-1506, Rev. 0

This page intentionally left blank. 
HNF-1506, Rev. 0

\section{CONTENTS}

1.0 INTRODUCTION ..................... 7

2.0 THERMAL ANALYSIS OF THERMO-GRAVIMETRIC ANALYSIS SAMPLE TEMPERATURES 9

2.1 ADIABATIC TEMPERATURE RISE .............. 9

2.2 FORCED CONVECTION HEAT TRANSFER . . . . . . . . . 11

2.3 CONVECTION, RADIATION, AND CONDUCTION HEAT TRANSFER . . . . 11

2.4 SENSITIVITY OF CONTACT AREA . . . . . . . . . . . 13

3.0 RESPONSE TIME OF SAMPLE THERMOCOUPLE . . . . . . . . . 15

4.0 SPENT NUCLEAR FUEL OXIDATION RATE AT THE CALCULATED TEMPERATURES . . 17

5.0 WATER EVAPORATION TEST . . . . . . . . . . . . . 19

6.0 REFERENCES ......................... 21

APPENDIX A FURTHER ANALYSIS AND CONCLUSIONS RELATED TO SNFCT 97:004 AND OTHER THERMO-GRAVIMETRIC ANALYSIS BASED ON OXIDATION STUDIES ................. A-1

APPENDIX B CALCULATIONAL SHEETS FOR THERMAL ANALYSIS OF THERMOGRAVIMETRIC ANALYSIS OF SAMPLE TEMPERATURES .... B 1 
HNF-1506, Rev. 0

\section{LIST OF FIGURES}

1. Schematic of the Fuel Oxidation Samples in the ThermoGravimetric Analysis System .............. 10

2. Response of the Sample Thermocouple to Temperature Changes During the Water Evaporation at Ambient Condition ........ 20

\section{LIST OF TABLES}

1. Calculated Spent Nuclear Fuel Sample Temperatures for Adiabatic Temperature Rise . . . . . . . . . . . . .

2. Calculated Spent Nuclear Fuel Sample Temperatures for Forced Convection Analysis . . . . . . . . . . . . . . .

3. Calculated Spent Nuclear Fuel Sample Temperatures for $0.5 \mathrm{~mm}$ Gap Under the Sample . . . . . . . . . . .

4. Calculated Spent Nuclear Fuel Sample Temperatures for $1 \%$ Area Contact with Crucible .............

5. Calculated Spent Nuclear Fuel Sample Temperatures for $10 \%$ Contact with Crucible ...............

6. Calculated Spent Nuclear Fuel Oxidation Rate for the Forced Convection Temperatures 
HNF-1506, Rev. 0

\section{THERMAL ANALYSIS OF THERMO-GRAVIMETRIC MEASUREMENTS OF SPENT NUCLEAR FUEL OXIDATION RATES}

\subsection{INTRODUCTION}

The oxidation rates of $\mathbf{N}$ Reactor Spent Nuclear Fuel (SNF) stored in the Hanford K Basins are being measured using a Thermo-Gravimetric Analysis (TGA) system at the Pacific Northwest National Laboratory. Sample temperatures, as measured with a thermocouple positioned in the TGA adjacent to the sample container did not increase as postulated as a result of the exothermic reactions. A series of calculations conducted by $R$. G. Ballinger suggested actual sample temperatures may be significantly higher than the temperatures measured and reported with the corresponding oxidation data (Appendix A). A detailed thermal analysis was conducted in response to this postulated difference between actual and measured sample temperatures.

The first step in the analysis was to verify Ballinger's calculations for both the adiabatic and forced convection heat transfer models he selected. These analyses were considered to be scoping in nature and consequently a more detailed and realistic model was selected for these analysis. Actual measurements of a sample under conditions known and calculated to result in a change in sample temperatures were conducted. A measured amount of water was placed in the sample holder and the water was removed by evaporation at ambient temperatures under vacuum conditions. The results of the test showed that the decrease in temperatures due to the evaporation process was measured by the sample thermocouple, thereby establishing the sensitivity of the sample thermocouple to temperature changes. 
HNF-1506, Rev. 0

This page intentionally left blank. 
HNF-1506, Rev. 0

\subsection{THERMAL ANALYSIS OF THERMO-GRAVIMETRIC ANALYSIS SAMPLE TEMPERATURES}

A sample of SNF was placed in the TGA in a small quartz crucible that was open at the top. The crucible was placed on an alumina pedestal inside a 1.15 in. diameter furnace (Figure 1). The SNF sample was oxidized with dry air flowing through the furnace at about $250 \mathrm{~cm}^{3} /$ minute.

The sample temperature was measured with a thermocouple that was held inside the alumina pedestal head, just under the crucible containing the SNF sample. This thermocouple read nearly the same as the furnace (test) temperature for all of the oxidation tests. The SNF sample thermocouple will 7 ag rapid changes in sample temperature but will gradually approach the sample temperature exponentially with a time constant that is very fast (about $1.0 \mathrm{~s}$ ) if the thermocouple is in good thermal contact with the SNF sample. This time constant is much longer (up to 3 minute) if the thermocouple and SNF sample are not in good thermal contact.

Heat can be transferred from the SNF sample in three ways: by convection and by radiation from the top surface and by conduction from the bottom surface. Very little heat will be removed from the sides of the sample because it is effectively insulated by stagnant air inside the crucible and also because the crucible acts as a thermal radiation shield between the sample and the furnace wall.

The results of the adiabatic calculation, forced convection model, and more detailed models considering convection, radiation, and conduction are summarized in the following sections of this report. The calculation sheets for these different models are included in Appendix B.

\subsection{ADIABATIC TEMPERATURE RISE}

The first analysis of the SNF sample conducted by Ballinger assumed that there is no heat transfer at all from the sample and that all of the reaction generated heat goes into raising the sample temperature (Appendix A). This assumption is not realistic but it does give an upper bound of the sample temperature.

The sample temperature rise was calculated with the following equation, where $q$ is the reaction heat measured with the TGA system and $m, C p$, and $\Delta T$ are the sample mass, heat capacity, and temperature rise.

$$
q=m C p \Delta T
$$

Results of the calculations are summarized in Table 1. This initial analysis which was verified by these repeat calculations does support the contention that TGA sample temperatures could be significantly higher than the temperature reported for oxidation. 
Figure 1. Schematic of the Fuel Oxidation Samples

in the Thermo-Gravimetric Analysis System.

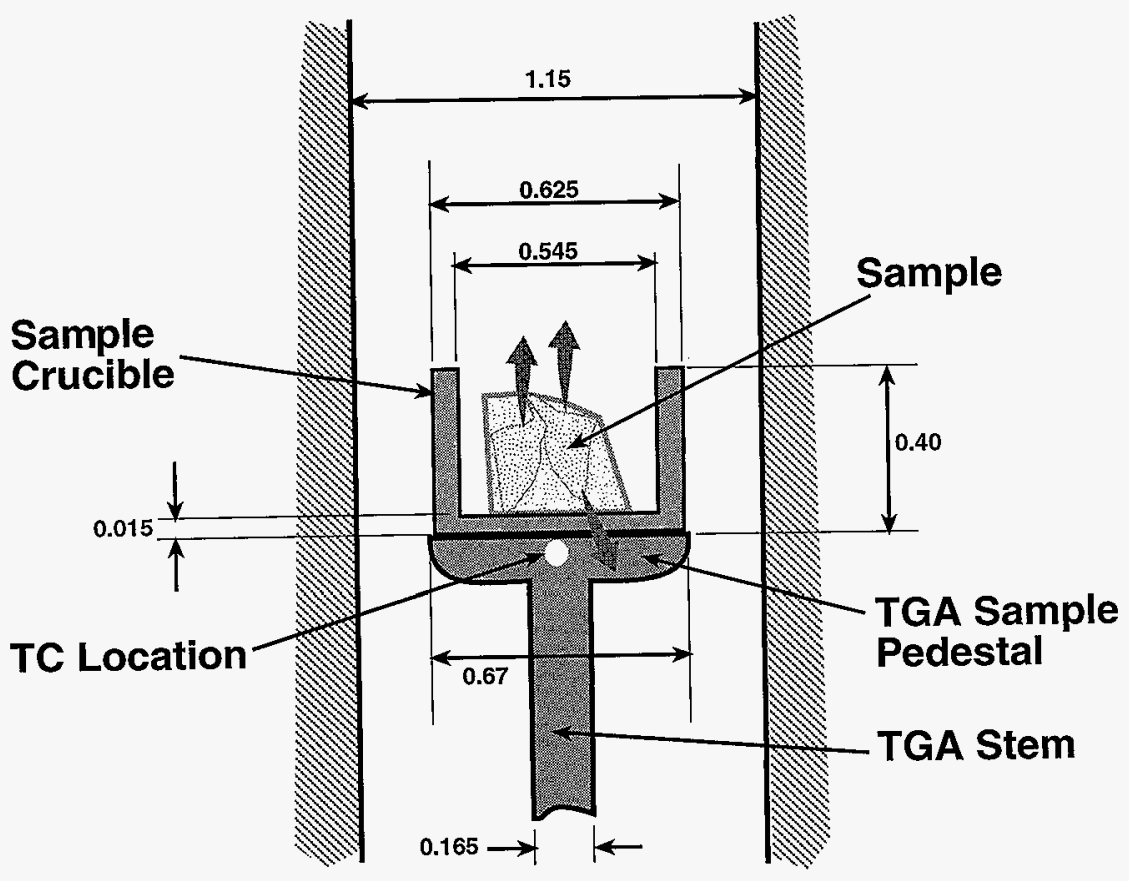

Dimensions in Inches

97080186.1 
HNF-1506, Rev. 0

\subsection{FORCED CONVECTION HEAT TRANSFER}

A second analysis was performed by Ballinger which modeled the SNF sample as a sphere suspended in a gas stream flowing in a pipe. Heat transfer from the sample was calculated only for convection to the flowing air. The convective heat transfer correlation used for this analysis is:

$$
\mathrm{N} u=2+\left(0.4 R e^{.5}+0.06 R e^{2 / 3}\right) \operatorname{Pr}^{.4}\left(\frac{\mu_{\text {stream }}}{\mu_{\text {wall }}}\right)^{.25}
$$

where $\mathrm{Re}$ is the Reynolds number based on the sphere diameter, $\mathrm{Pr}$ is the Prandt 1 number, and $\mu_{\text {stream }}$ and $\mu_{\text {wall }}$ are the viscosity of the gas evaluated at the free stream temperature and the sample surface temperature respectively. For this analysis it was assumed that the free stream and wall viscosity were equat.

This was also not a realistic analysis because the SNF sample is actually in thermal contact with the alumina pedestal by conduction and with the graphite furnace wall by radiative heat transfer. Conduction to the alumina pedestal is actually quite effective because alumina has a relatively high conductivity and it acts as a fin to dissipate heat generated by the SNF sample. The radiative heat transfer is also quite effective because the graphite furnace wall has a very high emissivity.

Because the air flow rate through the furnace is very low (the average velocity is $0.02 \mathrm{ft} / \mathrm{s}$ ) the SNF sample temperatures that were calculated by this analysis are not expected to be close to the actual temperatures. This analysis was however, repeated and the results compared to Ballinger (Appendix A) and the results are given in Table 2.

Temperatures were again found to be higher than the reported values and in some cases significantly higher.

\subsection{CONVECTION, RADIATION, AND CONDUCTION HEAT TRANSFER}

The two analyses described above, while not actually credible, did raise a valid concern that the SNF sample temperature may be significantly different from the measured temperature. More realistic analyses were then performed to determine whether this concern is really valid. These analyses were difficult to perform precisely because the exact geometry of the SNF sample, quartz crucible, and alumina pedestal is not known. But sensitivity analyses were performed and these analyses show that the actual SNF sample temperature is probably quite close to the measured temperature for most of the oxidation rate tests.

This more realistic analysis considered radiative and convective heat transfer from the top surface and conductive heat transfer from the bottom surface. 


$$
\text { HNF-1506, Rev. } 0
$$

The convective heat transfer from the top surface was calculated by

$$
q=h A \Delta T
$$

where $\Delta T$ is the difference between the sample temperature and the gas temperature. The gas temperature was assumed to be equal to the measured furnace temperature. The convection heat transfer coefficient, $h$, was estimated to be $2.0 \mathrm{Btu} / \mathrm{hr}-\mathrm{ft}^{2}-\mathrm{F}$.

The radiative heat transfer from the top surface of the sample was calculated by:

$$
\mathrm{q}=A F \sigma\left(T_{G}^{4}-T_{F}^{4}\right)
$$

where $F$ is the gray-body shape factor, $\sigma$ is the Stephan-Boltzman constant, $T_{s}$ is the sample temperature and $T_{f}$ is the measured furnace temperature. An emissivity of 0.7 was used for the SNF surface and an emissivity of 0.98 was used for the graphite furnace wall.

The SNF sample was not cut perfectly flat and a small layer of air may have existed under the sample (Figure 1). It has been estimated that this air gap is up to $1 \mathrm{~mm}$ thick. Of course, some part of the bottom of the sample must be in contact with the crucible and there will be a significant amount of heat flow through that contact area.

The calculation of conduction heat transfer from the bottom surface assumed a uniform layer of air of $0.5 \mathrm{~mm}$ thickness between the sample and the crucible. This calculation was conservative because no credit was taken for conduction through any contact area between the sample and the crucible.

The equation to account for conduction is:

$$
\mathrm{q}=\frac{K A \Delta T}{I}
$$

where $K$ is the thermal conductivity of the air layer presumed to be under the sample and 1 is the air gap thickness. The thermal resistance of the quartz crucible was neglected because the conductivity of quartz is approximately 100 times that of air.

The SNF sample temperatures calculated by this method are shown in Table 3. Of the total heat transfer calculated from the sample, $9 \%$ is by convection from the top surface, $24 \%$ is by radiation from the top surface (for $300{ }^{\circ} \mathrm{C}$ test temperature), and $67 \%$ is by conduction through the air gap under the sample. These results still indicate that the SNF sample temperature is higher than the furnace temperature so more realistic assumptions than a uniform air gap are required. 


\subsection{SENSITIVITY OF CONTACT AREA}

Because the area of contact between the SNF sample and the crucible is not known and is probably different for each sample, a sensitivity analys is was performed with variable amounts of the sample bottom surface in good contact with the crucible. The sample temperatures were calculated for $1 \%$ and $10 \%$ area contact and the resulting temperatures are given in Tables 4 and 5 .

The heat flow through the contact area considered the thermal resistance of the quartz crucjble over an area equal to the presumed contact area in series with a smaller thermal resistance for the SNF sample and another small resistances for the alumina pedestal. These three resistance were combined in series to get an overall conductance, $U$, through the contact area:

$$
\mathrm{U}=\frac{1}{\frac{I_{s}}{K_{S} A_{S}}+\frac{I_{q}}{K_{q} A_{q}}+\frac{I_{a}}{k_{a} A_{a}}}
$$

where $s, q$, and $a$, refer to the sample, quartz crucible, and alumina pedestal. This conductance was added to the convection, radiation, and conduction heat transfer described in Section 2.3.

In the case of a $1 \%$ contact area the maximum difference between test temperatures and the calculations was approximately $40^{\circ} \mathrm{C}$ with an average of approximately $15{ }^{\circ} \mathrm{C}$. For a $10 \%$ contact area the maximum difference was reduced to approximately $10^{\circ} \mathrm{C}$ with an average of less than $5{ }^{\circ} \mathrm{C}$.

The analysis considering $10 \%$ contact between the sample and the crucible is considered to be more realistic of the actual test conditions. Therefore, actual sample temperatures are estimated to be within $\pm 10^{\circ} \mathrm{C}$ or less of the measured values reported for the oxidation data and no adjustments to the reported data for sample temperatures are necessary. 
HNF-1506, Rev. 0

This page intentionally left blank. 
HNF-1506, Rev. 0

\subsection{RESPONSE TIME OF SAMPLE THERMOCOUPLE}

The time constant of the sample thermocouple was calculated to be $2.7 \mathrm{~s}$ if the thermocouple is in good thermal contact with the SNF sample. It was calculated to be $167 \mathrm{~s}$ if it is insulated from the sample by an air gap. The time constant is the time required for the thermocouple to reach $63 \%$ of a step change in the surface temperature of the SNF sample and is given by:

$$
\tau=\frac{\rho V C p}{h A}
$$

where $\rho, V$, and $C p$ are the uranium density, volume, and heat capacity and $A$ is the heat transfer area. The heat transfer coefficient, $h$, in the above equation is the effective heat transfer coefficient from the surface of the SNF sample (where the heat generation will be) to the thermocouple. The derivation of this equation can be found in any heat transfer text book.

If the thermocouple is in good thermal contact with the SNF sample, the heat transfer coefficient is the combined coefficient for the sample and the quartz crucible. If the thermocouple is not in good thermal contact, another term is included in the heat transfer coefficient for the air gap between the sample and the quartz crucible. The air gap thermal resistance is potentially much larger than the other two resistances. For this calculation it was assumed that the average thickness of the air gap was $0.5 \mathrm{~mm}$.

The calculation sheets for this analysis are also included in Appendix B. 
HNF-1506, Rev. 0

This page intentionally left blank. 


\subsection{SPENT NUCLEAR FUEL OXIDATION RATE AT THE CALCULATED TEMPERATURES}

The kinetics of a temperature-activated reaction is strongly influenced by the accurate measurement of the sample temperature. The exothermic reaction of metallic uranium in dry air can increase the sample temperature if the heat generated by the sample is not dissipated in the experimental system. Any changes in the sample temperature, if not detected by the sample thermocouple, and consequently taken into account in the analysis can result in inaccurate comparison of the experimental data with the theoretical data. The oxidation kinetics of SNF (uranium metal) in dry air was analyzed (Abrefah 1996) with the assumption that the measured temperatures were accurate within experimental error. The measured rate constant (Abrefah 1996) was higher than the theoretical estimate based on the rate equation of Pearce et al. (Pearce 1988). This higher rate was ascribed to the characteristics of the irradiated and damaged $N$ Reactor fuel, however, the postulated differences in measured and actual sample temperatures could account partially for the increased reactivity. Thus, the samples may have been at higher temperatures than was measured by the sample thermocouple.

The estimated temperatures calculated by Ballinger (Appendix A) were used to estimate an oxidation rate for the $N$ Reactor fuel samples using the dry air rate equation of Pearce et al. (Pearce 1988). The calculated oxidation rates were compared to the reported experimental rates in Table 6 for the forced convection analysis.

If you assume no differences in the oxidation rates of the damaged $N$ Reactor irradiated fuel and the literature, i.e., Pearce equation, and the temperatures calculated by Ballinger for the forced convection analys is are of the proper magnitude then there should be some level of comparison or a consistent difference between the measured and calculated oxidation rates. Comparing the measured oxidation rates to the calculated values shows in general no agreement or consistent differences (Table 6).

This comparison suggests that the temperatures calculated using the forced convection analysis do not represent the actual sample temperatures. If there was a systematic difference between the literature values of oxidation rates, i.e., Pearce equation, and the $\mathrm{N}$ Reactor fuel data and the calculated temperatures in general represented the sample temperatures then there would be a consistent difference or trend which was not the case for the data sets in question. The conclusion from this comparison supports the thermal analysis (Section 2.0) that sample temperatures are closer to measured temperatures than the forced convection analysis suggests. 
HNF-1506, Rev. 0

This page intentionally left blank. 
HNF-1506, Rev. 0

\subsection{WATER EVAPORATION TEST}

The TGA quartz crucible used for the SNF oxidation studies was filled with about $300 \mathrm{mg}$ of water for an evaporation test at room temperature. The objective of the test was to test the responsiveness of the TGA sample thermocouple to changes in the sample temperature. The system was pumped down to initiate the evaporation of the water. The system pressure, sample temperature and weight loss due to the evaporation of the water were monitored continuously. The response of the sample thermocouple to temperature changes during the water evaporation is plotted in Figure 2 together with the weight 1oss. The general observations of the test are,

- The sample thermocouple decreased from ambient conditions of about $29^{\circ} \mathrm{C}$ to as low as $14^{\circ} \mathrm{C}$ and maintained the drop in temperature until most of the water has evaporated.

- The sample thermocouple returned to ambient temperature condition after all the water had evaporated.

- Calculations with the assumption of an adiabatic condition and averaged linear evaporation rate yielded a temperature decrease rate of about $5{ }^{\circ} \mathrm{C} /$ minute. The maximum temperature drop rate observed was about $2.4^{\circ} \mathrm{C} /$ minute.

The results of the test suggest that

- Changes in the sample temperature by reaction can be detected by the TGA sample thermocouple.

- A fraction of the heat loss may be dissipated to other parts of the system through the three heat transfer processes. Radiation at these low temperatures will have negligible contribution to heat 1oss. The system was evacuated during the test and thus, will minimize any heat transfer mechanism by convection. Therefore, the dominant heat loss mechanism was conduction consistent with the thermal analysis (Section 2.3). The dominant heat loss mechanism for the sample is conduction down the stem of the sample holder.

- The return of the sample thermocouple to ambient conditions following the complete evaporation of the water was a demonstration of proper thermocouple behavior. 
HNF-1506, Rev. 0

Figure 2, Response of the Sample Thermocouple to Temperature Changes During the Water Evaporation at Ambient Condition.

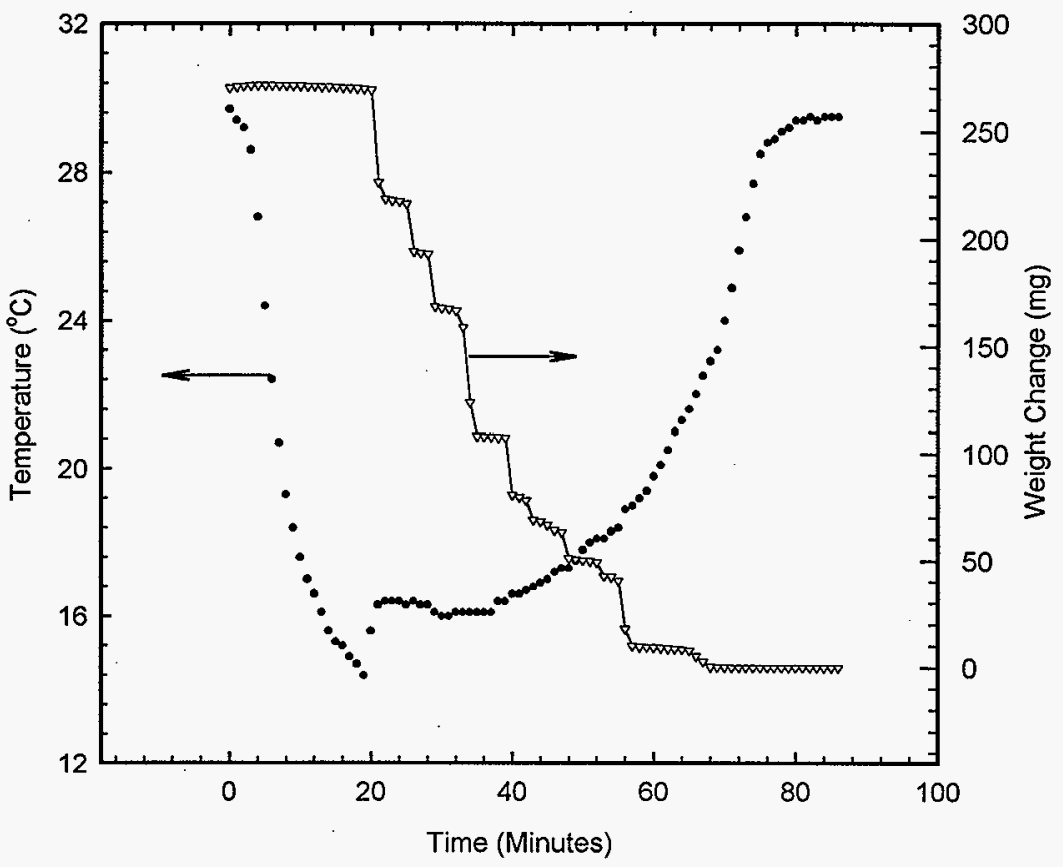


HNF-1506, Rev. 0

This page intentionally left blank. 
HNF-1506, Rev. 0

\subsection{REFERENCES}

Abrefah J., H. C. Buchanan, and S. C. Marschman, 1996, Oxidation Kinetics of K-West Spent Nuclear Fuel in Dry Air, SNFCT97:004, Pacific Northwest Nationa 1 Laboratory, Rich 7 and, Washington.

Pearce, R. J., M. J. Bennet, and J. B. Price, 1988, "Oxidation of Irradiated Uranium in Moist Air," Nuclear Energy $27(5): 305$. 
Table 1. Calculated Spent Nuclear Fuel Sample Temperatures for Adiabatic Temperature Rise.

\begin{tabular}{||c|c|c|c|c|c||}
\hline \multirow{2}{*}{$\begin{array}{l}\text { TGA } \\
\text { Run }\end{array}$} & $\begin{array}{c}\text { Test } \\
\text { Temp. } \\
\left({ }^{\circ} \mathrm{C}\right)\end{array}$ & $\begin{array}{c}\text { Sample } \\
\text { Weight } \\
(\mathrm{g})\end{array}$ & $\mathrm{dW}(\mathrm{mg})$ & \multicolumn{2}{|c|}{ Calculated Sample Temp. ${ }^{\circ} \mathrm{C}$} \\
\cline { 5 - 7 } & & $\begin{array}{c}\text { R.G. Ballinger } \\
\text { Results }\end{array}$ & $\begin{array}{c}\text { E.R. Cramer } \\
\text { Results }\end{array}$ \\
\hline 18 & 144 & 5.41 & $6.5(6 \mathrm{~min})$ & 338 & 482 \\
& 144 & 5.41 & $2.5(20 \mathrm{~min})$ & 273 & 273 \\
\hline 23 & 150 & 3.32 & $0.15(70 \mathrm{~min})$ & 162 & 162 \\
\hline $18 b$ & 150 & 6.35 & $0.2(5 \mathrm{~min})$ & 160 & 159 \\
& 150 & 6.35 & $0.4(1 \mathrm{~min})$ & 187 & 168 \\
\hline 7 & 150 & 6.35 & $3.1(5 \mathrm{~min})$ & 287 & 287 \\
\hline & 300 & 6.88 & $8(20 \mathrm{~min})$ & 627 & 627 \\
& 300 & 6.88 & $3(10 \mathrm{~min})$ & 422 & 422 \\
\hline $21 \mathrm{a}$ & 300 & 6.88 & $5(25 \mathrm{~min})$ & 504 & 504 \\
\hline 22 & 300 & 6.88 & $7(10 \mathrm{~min})$ & 586 & 586 \\
\hline
\end{tabular}

Table 2. Calculated Spent Nuclear Fuel Sample

Temperatures for Forced Convection Analys is.

\begin{tabular}{||c|c|c|l|c|c||}
\hline \multirow{2}{*}{$\begin{array}{l}\text { TGA } \\
\text { Run }\end{array}$} & $\begin{array}{c}\text { Test } \\
\text { Temp. } \\
\left({ }^{\circ} \mathrm{C}\right)\end{array}$ & $\begin{array}{c}\text { Sample } \\
\text { Weight } \\
(\mathrm{g})\end{array}$ & $\mathrm{dW}(\mathrm{mg})$ & \multicolumn{2}{|c|}{ Calculated Sample Temp. ${ }^{\circ} \mathrm{C}$} \\
\cline { 5 - 6 } & & $\begin{array}{c}\text { R.G. Ballinger } \\
\text { Results }\end{array}$ & $\begin{array}{c}\text { E.R. Cramer } \\
\text { Results }\end{array}$ \\
\hline 18 & 144 & 5.41 & $6.5(6 \mathrm{~min})$ & 238 & 356 \\
& 144 & 5.41 & $2.5(20 \mathrm{~min})$ & 155 & 168 \\
\hline 23 & 150 & 3.32 & $0.15(70 \mathrm{~min})$ & 150 & 150 \\
\hline $18 \mathrm{~b}$ & 150 & 6.35 & $0.2(5 \mathrm{~min})$ & 153 & 158 \\
& 150 & 6.35 & $0.4(1 \mathrm{~min})$ & 181 & 228 \\
& 150 & 6.35 & $3.1(5 \mathrm{~min})$ & 191 & 271 \\
\hline 7 & 300 & 6.88 & $8(20 \mathrm{~min})$ & 342 & 378 \\
& 300 & 6.88 & $3(10 \mathrm{~min})$ & 331 & 359 \\
& 300 & 6.88 & $5(25 \mathrm{~min})$ & 321 & 339 \\
\hline $21 \mathrm{a}$ & 300 & 6.88 & $7(10 \mathrm{~min})$ & 374 & 437 \\
\hline 22 & 350 & 6.04 & $2.5(10 \mathrm{~min})$ & 320 & 349 \\
\hline
\end{tabular}


Table 3. Calculated Spent Nuclear Fuel Sample Temperatures for $0.5 \mathrm{~mm}$ Gap Under the Sample.

\begin{tabular}{||l|c|c|l|c||}
\hline $\begin{array}{c}\text { TGA } \\
\text { Run }\end{array}$ & $\begin{array}{c}\text { Test } \\
\text { Temp. } \\
\left({ }^{\circ} \mathrm{C}\right)\end{array}$ & $\begin{array}{c}\text { Sample } \\
\text { Weight } \\
(\mathrm{g})\end{array}$ & \multicolumn{1}{c|}{$\mathrm{dW}(\mathrm{mg})$} & $\begin{array}{c}\text { CaTculated } \\
\text { Sample } \\
\text { Temp. }{ }^{\circ} \mathrm{C}\end{array}$ \\
\hline 18 & 144 & 5.41 & $6.5(6 \mathrm{~min})$ & 207 \\
& 144 & 5.41 & $2.5(20 \mathrm{~min})$ & 151 \\
\hline 23 & 150 & 3.32 & $0.15(70 \mathrm{~min})$ & 150 \\
\hline $18 \mathrm{~b}$ & 150 & 6.35 & $0.2(5 \mathrm{~min})$ & 152 \\
& 150 & 6.35 & $0.4(1 \mathrm{~min})$ & 173 \\
& 150 & 6.35 & $3.1(5 \mathrm{~min})$ & 186 \\
\hline 7 & 300 & 6.88 & $8(20 \mathrm{~min})$ & 320 \\
& 300 & 6.88 & $3(10 \mathrm{~min})$ & 315 \\
& 300 & 6.88 & $5(25 \mathrm{~min})$ & 310 \\
& 300 & 6.88 & $7(10 \mathrm{~min})$ & 335 \\
\hline $21 \mathrm{a}$ & 300 & 6.04 & $2.5(10 \mathrm{~min})$ & 313 \\
\hline 22 & 350 & 5.93 & $13(10 \mathrm{~min})$ & 409 \\
\hline
\end{tabular}

Table 4. Calculated Spent Nuclear Fuel Sample Temperatures for $1 \%$ Area Contact with Crucible.

\begin{tabular}{||l|c|c|l|c||}
\hline $\begin{array}{c}\text { TGA } \\
\text { Run }\end{array}$ & $\begin{array}{c}\text { Test } \\
\text { Temp. } \\
\left({ }^{\circ} \mathrm{C}\right)\end{array}$ & $\begin{array}{c}\text { Sample } \\
\text { Weight } \\
(\mathrm{g})\end{array}$ & \multicolumn{1}{c|}{$\mathrm{dW}(\mathrm{mg})$} & $\begin{array}{c}\text { Calculated } \\
\text { Samp Te } \\
\text { Temp. }{ }^{\circ} \mathrm{C}\end{array}$ \\
\hline 18 & 144 & 5.41 & $6.5(6 \mathrm{~min})$ & 184 \\
& 144 & 5.41 & $2.5(20 \mathrm{~min})$ & 149 \\
\hline 23 & 150 & 3.32 & $0.15(70 \mathrm{~min})$ & 150 \\
\hline $18 \mathrm{~b}$ & 150 & 6.35 & $0.2(5 \mathrm{~min})$ & 151 \\
& 150 & 6.35 & $0.4(1 \mathrm{~min})$ & 165 \\
& 150 & 6.35 & $3.1(5 \mathrm{~min})$ & 173 \\
\hline 7 & 300 & 6.88 & $8(20 \mathrm{~min})$ & 313 \\
& 300 & 6.88 & $3(10 \mathrm{~min})$ & 310 \\
& 300 & 6.88 & $5(25 \mathrm{~min})$ & 307 \\
\hline $21 \mathrm{a}$ & 300 & 6.88 & $7(10 \mathrm{~min})$ & 323 \\
\hline 22 & 350 & 6.04 & $2.5(10 \mathrm{~min})$ & 308 \\
\hline \hline
\end{tabular}


HNF-1506, Rev. 0

Table 5. Calculated Spent Nuclear Fuel Sample

Temperatures for $10 \%$ Contact with Crucible.

\begin{tabular}{||c|c|c|l|c||}
\hline $\begin{array}{c}\text { TGA } \\
\text { Run }\end{array}$ & $\begin{array}{c}\text { Test } \\
\text { Temp. } \\
\left({ }^{\circ} \mathrm{C}\right)\end{array}$ & $\begin{array}{c}\text { Sample } \\
\text { Weight } \\
(\mathrm{g})\end{array}$ & \multicolumn{1}{|c|}{$\mathrm{dW}(\mathrm{mg})$} & $\begin{array}{c}\text { Calculated } \\
\text { Sample } \\
\text { Temp. }{ }^{\circ} \mathrm{C}\end{array}$ \\
\hline 18 & 144 & 5.41 & $6.5(6 \mathrm{~min})$ & 153 \\
& 144 & 5.41 & $2.5(20 \mathrm{~min})$ & 145 \\
\hline 23 & 150 & 3.32 & $0.15(70 \mathrm{~min})$ & 150 \\
\hline $18 \mathrm{~b}$ & 150 & 6.35 & $0.2(5 \mathrm{~min})$ & 150 \\
& 150 & 6.35 & $0.4(1 \mathrm{~min})$ & 153 \\
& 150 & 6.35 & $3.1(5 \mathrm{~min})$ & 155 \\
\hline 7 & 300 & 6.88 & $8(20 \mathrm{~min})$ & 303 \\
& 300 & 6.88 & $3(10 \mathrm{~min})$ & 302 \\
& 300 & 6.88 & $5(25 \mathrm{~min})$ & 302 \\
\hline $21 \mathrm{a}$ & 300 & 6.88 & $7(10 \mathrm{~min})$ & 306 \\
\hline 22 & 350 & 6.04 & $2.5(10 \mathrm{~min})$ & 302 \\
\hline
\end{tabular}


Table 6. CaTculated Spent Nuclear Fuel 0xidation Rate for the Forced Convection Temperatures.

\begin{tabular}{|c|c|c|c|c|c|}
\hline $\begin{array}{c}\text { TGA } \\
\text { Run \# }\end{array}$ & $\begin{array}{c}\text { Test } \\
\text { Temperature } \\
\left({ }^{\circ} \mathrm{C}\right)\end{array}$ & $\begin{array}{c}\text { Ballinger } \\
\text { Calculated } \\
\text { Temperature } \\
\left({ }^{\circ} \mathrm{C}\right)\end{array}$ & $\begin{array}{c}\text { Observed } \\
\text { Rate } \\
\left(\mathrm{mg} / \mathrm{cm}^{2} \cdot \min \right) \\
\end{array}$ & $\begin{array}{c}\text { Calculated } \\
\text { Rate } \\
\left(\mathrm{mg} / \mathrm{cm}^{2 *} \cdot \min \right)\end{array}$ & $\begin{array}{c}\text { Observed Rate/ } \\
\text { Calculated Rate }\end{array}$ \\
\hline 18 & $\begin{array}{l}144 \\
144 \\
\end{array}$ & $\begin{array}{l}238 \\
155 \\
\end{array}$ & $\begin{array}{l}0.43 \\
0.049 \\
\end{array}$ & $\begin{array}{r}0.012 \\
2.2 \times 10^{-4} \\
\end{array}$ & $\begin{array}{r}36 \\
223 \\
\end{array}$ \\
\hline 23 & 150 & 150 & $1.7 \times 10^{-3}$ & $1.6 \times 10^{-4}$ & 11 \\
\hline $18 b$ & $\begin{array}{l}150 \\
150 \\
150 \\
\end{array}$ & $\begin{array}{l}153 \\
181 \\
191 \\
\end{array}$ & $\begin{array}{l}0.015 \\
0.15 \\
0.24 \\
\end{array}$ & $\begin{array}{l}1.9 \times 10^{-4} \\
9.0 \times 10^{-4} \\
1.5 \times 10^{-3} \\
\end{array}$ & $\begin{array}{r}79 \\
167 \\
160 \\
\end{array}$ \\
\hline 7 & $\begin{array}{l}300 \\
300 \\
300 \\
300 \\
\end{array}$ & $\begin{array}{l}342 \\
331 \\
321 \\
374 \\
\end{array}$ & $\begin{array}{l}0.14 \\
0.10 \\
0.070 \\
0.24\end{array}$ & $\begin{array}{l}0.42 \\
0.31 \\
0.23 \\
1.0 \\
\end{array}$ & $\begin{array}{l}0.3 \\
0.3 \\
0.3 \\
0.2 \\
\end{array}$ \\
\hline $21 a$ & 300 & 320 & 0.10 & 0.22 & 0.5 \\
\hline 22 & 350 & 455 & 0.52 & 6.3 & 0.08 \\
\hline
\end{tabular}

*Estimated from the weight gain, $d W$, in Table 1 and the initial sample geometrical area.

**Calculated using the dry air oxidation rate equation of Pearce et al.

(Pearce 1988) and the calculated temperature of R. G. Ballinger. 
HNF-1506, Rev. 0

A P PEN DIX A

FURTHER ANALYSIS AND CONCLUSIONS RELATED TO SNFCT97:004 AND OTHER THERMO-GRAVIMETRIC ANALYSIS BASED

ON OXIDATION STUDIES

A-1 
HNF-1506, Rev, 0

\section{Spent Nuclear Fuel Technical Assistance Group(TAG)}

J. C. DeVine (Head), Polestar Applied Technology

Bldg. 2752E-F107

R. G. Ballinger, Massachusetts Institute of Technology

Phone 509-373-7755

T. L. Bradley, Duke Engineering \& Services

FAX (509) 372-2303

D. G. Strawson, MPR Associates

R. H. Steele, MPR Associates

J. D. Trotter, Polestar Applied Technology

R.F. Williams, WTA

\section{MEMO}

To:

Dr. P. G. Loscoe

From:

R. G. Ballinger

CC:

J. C. DeVine

Date: 4/16/97

Subject:

Further Analysis \& Conclusions Related to SNFCT97:004 and Other TGA Based Oxidation Studies

A detailed analysis of the data presented in SNFCT97:004 was presented in an earlier report [1]. One of the conclusions of this analysis was that the data presented in SNFCT97:004 represented a number of processes which were occurring simultaneously during the IGA runs and that analysis of the data must take this into account in deriving any information concerning rates of oxidation. One of the phenomena that was postulated to be occurring was the cracking up of the samples which exposed fresh metal to the environment. Exposure of fresh metal to the environment resulted in regions of the sample which would react at a much higher, parabolic, rate than other regions of the sample which were oxidizing in the linear regime. This process manifested itself as sharp jumps in the weight gain over short intervals of time. Since essentially all (all but one instance) of these jumps were not accompanied by a simultaneous burst of hydrogen the likelihood of these events being due to hydride reaction events was considered very small. The above conclusions are still considered valid. However, the author has further analyzed these jumps in weight gain to evaluate the potential effect of reaction generated heat in aggravating the process during these events. The sample temperature is the critical parameter in establishing the rate of reaction. $\mathrm{A} 10^{\circ} \mathrm{C}$ increase in temperature can be expected to result in an approximate factor of two in the reaction rate [2]. Thus, the generation of substantial reaction heat (1080 kJ/moleU for the uranium-oxygen reaction) could result in a "positive feedback" situation in which, if the heat is not adequately removed by the atmosphere, reaction heat increases sample temperature which further increases the reaction rate and so on until very high temperatures are reached. The possibility for this situation occurring was investigated and is reported here.

Two sets of analysis were conducted: (1) an estimate of the adiabatic temperature increase which could occur during rapid weight gain events and (2) a analysis of the effect of forced convection heat transfer to the gas stream on reducing sample surface temperature during a rapid weight gain event.

\subsection{Adiabatic Temperature Rise}

For this analysis it was assumed that ail of the reaction generated heat during a rapid weight gain event went into raising the sample temperature. The specific heat of uranium metal was assumed to be constant at $0.12 \mathrm{~J} / \mathrm{g}-\mathrm{K}$. A more rigorous analysis would take the variation of specific heat with temperature into account. However, as will be shown in the discussion, this assumption was adequate for this analysis.

\subsection{Forced Convection Heat Transfer}


HNF-1506, Rev. 0

The forced convection analysis was conducted by modeling the system as heat transfer from a sphere suspended in a gas stream flowing in a pipe. Since the author was not able to get the physical dimensions of the TGA apparatus and since the analysis was only considered preliminary it was assumed that the pipe diameter was $2.54 \mathrm{~cm}$. However, the assumption of spherical geometry will result in an upper bound on the heat transfer coefficient for the systern. Thus, for the purposes of the preliminary analysis one can assume that the actual sample surface temperature during a rapid oxidation event will lie between the adiabatic temperature and the forced convection wall temperature but much closer to the forced convection temperature. One additional consideration-the transient nature of the process must be considered in further analysis. As will be shown below, the time interval over which the event occurs is a critical parameter. In the extreme case where the event takes place instantaneously the actual surface temperature may be much closer to the adiabatic temperature.

The convective heat transfer correlation used for this analysis was that of Whitaker [3].

Where Re is the Reynolds number based on the sphere diameter; $\operatorname{Pr}$ is the Prandl Number, and $\mu$ is the viscosity of the . gas evaluated at the free stream temperature and the sample surface temperature respectively.

$$
N u=2+\left(0.4 \mathrm{Re}^{0.5}+0.06 \mathrm{Re}^{2 / 3}\right) \mathrm{Pr}^{0.4}\left(\frac{\mu_{\text {stream }}}{\mu_{\text {wall }}}\right)^{0.25}
$$

For this analysis it was assumed that the free stream and wall viscosity were equal. Based on the results of the analysis thus assumption would sesult in an error of approximately $20 \%$ in the heat transfer coefficient in the extreme case. This would result in an error of approximately $10^{\circ} \mathrm{C}$ in temperature.

Additional assumptions were that the gas properties were constant, independent of temperature as were the properties of uranium metal.

The analysis was programed using Mathead. The Mathead program is inclucied as Appendix 1.

\subsection{Results and Discussion}

The results of this analysis are shovn in Table l. The analysis was done using weight gain jumps in the TGA runs used to generate the data in SNFCT97:004. The effect of forced convection is very significant. However, for cases where the weight gain jump occurred over a short time period (<approximately $10 \mathrm{~min}$ ) it is likely that the sample temperature was so much higher than the gas temperature as to make any interpretation of the data for oxidation in this region meaningless. In fact, it is likely that a possible explanation for the weight loss after these events is that the sample surface temperature ramped up high enough and fast enough to literally cause something akin to ablation of the surface. Once the surface layer was "blown off" the high temperature material was removed and the sample was then free to oxidize at the free stream temperature. The ratio of specific heat to conductivity for uranium metal is approximately 0.5 . Thus for very fast transients one would expect that the sample temperature would not be uniform.

The effect of rapid heat introduction as a result of exposure of fresh metal coupled with inadequate heat removal has very likely resulted in the positive feedback phenomena suggested earlier. Thus it is very unlikely that the actual sample temperature was known within $20^{\circ} \mathrm{C}$ or even more for fast transients. Since many of these transients were used as the basis for data included in the PNNL rate law it is questionable weather the data and associated rate law are of any validity.

\subsection{Conclusions}

Based on this analysis the following conclusions are suggested: 
HNF-1506, Rev. 0

It is likely that the use of ANY rapid weight gain events (events ocurring over a period of time of the order of $10-20$ minutes) for the determination of rate law information should be approached with GREAT caution.

The value of ANY of the data generated as part of the TGA based oxidation studies will have a VERY high degree of uncertainty and, as such, can be expected to provide little information concerning the behavior of N-Reactor fuel.

Any oxidation and/or drying tests that are to be performed in the future should take due consideration of the heat transfer conditions as they effect actual sample temperatures during tests.

Table 1

Summary of Heating Aralysis

\begin{tabular}{|c|c|c|c|c|c|}
\hline Sample ID\# & Gas Temp.,C & Sample Wt,g & $\Delta W, \mathrm{mg}$ & $T$ (Adiabatic) & $\mathrm{T}_{\mathrm{w} z \text { (Conv.) }}$ \\
\hline $10-S 3-F 2(T G A 18)$ & $\begin{array}{l}144 \\
144\end{array}$ & $\begin{array}{l}5.41 \\
5.41\end{array}$ & $\begin{array}{l}6.5(6 \mathrm{~min}) \\
2.5(20 \mathrm{~min})\end{array}$ & $\begin{array}{l}338 \\
273\end{array}$ & $\begin{array}{l}238 \\
155\end{array}$ \\
\hline 5-SIA-E2-R1A(TGA23) & 150 & 3.32 & $0.15(70 \mathrm{~min})$ & 162 & 150 \\
\hline 10-S1-C4(TGA]86) & $\begin{array}{l}150 \\
150 \\
150\end{array}$ & $\begin{array}{l}6.35 \\
6.35 \\
6.35\end{array}$ & $\begin{array}{l}0.2(5 \mathrm{~min}) \\
0.4(1 \mathrm{~min}) \\
3.1(5 \mathrm{~min})\end{array}$ & $\begin{array}{l}160 \\
187 \\
287\end{array}$ & $\begin{array}{l}153 \\
181 \\
191\end{array}$ \\
\hline 5-S1A-A2C(TGA7) & $\begin{array}{l}300 \\
300 \\
300 \\
300\end{array}$ & $\begin{array}{l}6.88 \\
6.88 \\
6.88 \\
6.88\end{array}$ & $\begin{array}{l}8(20 \mathrm{~min}) \\
3(10 \mathrm{~min}) \\
5(25 \mathrm{~min}) \\
7(10 \mathrm{~min})\end{array}$ & $\begin{array}{l}627 \\
422 \\
504 \\
586\end{array}$ & $\begin{array}{l}342 \\
331 \\
321 \\
374\end{array}$ \\
\hline $10-\$ 1-C 3($ TGA21 a) & 300 & 6.04 & $2.5(10 \mathrm{~min})$ & 416 & 320 \\
\hline $10-\mathrm{S1}-\mathrm{C} 2(\mathrm{TGA} 22)$ & 350 & 5.93 & $13(10 \mathrm{~min})$ & 966 & 455 \\
\hline
\end{tabular}

\subsection{References}

1. Ballinger, R. G., "An Evaluation of Oxidation Data for N-Reactor Spent Nuclear Fuel in Diry and Moist Air", Report prepared for P. G. Loscoe, $4 / 6 / 97$.

2. Pearce, R. J., "A Review of the Rates of reaction of Unirradiated Uranium in Gaseous Atnospheres", CEGB Report $\mathrm{RD} / \mathrm{B} / 6231 / \mathrm{R} 89$, Ocober, 1989.

3. Whitaker, S., "Forced Convection Heat Transfer Correlations for Flow in Pipes Past Flat Plates, Single Cylinders, Single Spheres, and Flow in Packed Beds and Tube Bundles", AICHE J., Vol. 18, 1972, pp. 361-371. 
HNF-1506, Rev. 0

A P PEN D I X B

CALCULATIONAL SHEETS FOR THERMAL ANALYSIS OF THERMOGRAVIMETRIC ANALYSIS OF SAMPLE TEMPERATURES 
HNF-1506, Rev. 0

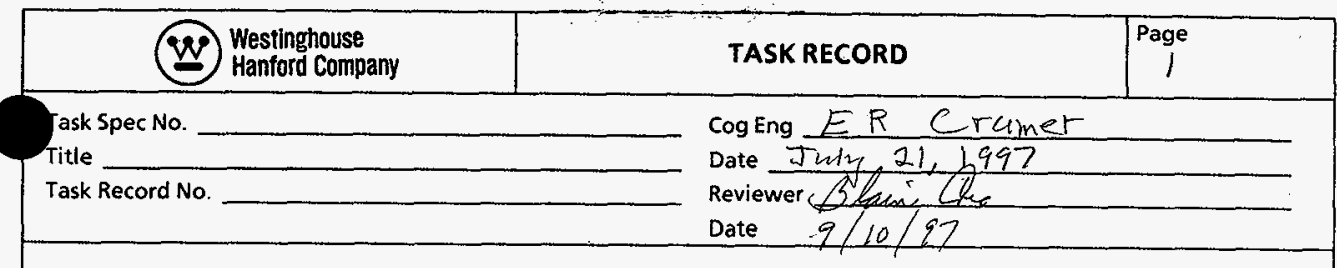

Calculation of SNF sample temperatures For Adiabatic temperature vise.

Assume all reaction generated heat goes into raising the sample temperature.

$$
\begin{aligned}
T & =T_{i}+\frac{\dot{q}}{m c_{p}} \\
\dot{q} & =(\Delta W)\left(33.075 \frac{T}{m g}\right)
\end{aligned}
$$

where $T_{i}=$ initial temperature, "C

$\dot{q}=$ heat input, joules

$m=$ sample mass, $m y$

$c_{p}=$ sample specific heat, $0.12 \frac{\mathrm{J}}{\mathrm{gk}}$

$\Delta W=$ sample weight gains, $m g$

$$
T=T_{i}+\frac{\Delta W(33.75)}{m(.12)}
$$

Results From this equation are given in Table 1. 
HNF-1506, Rev. 0

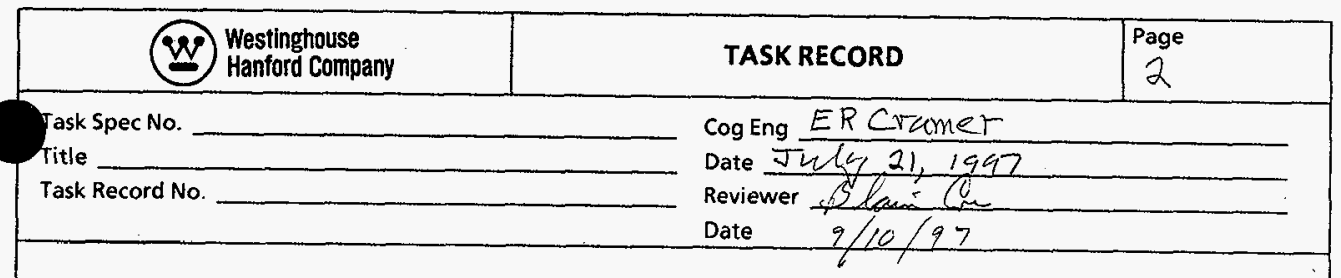

calculate temperature of SNF sample assuming Freed convection heat transfer.

use equation for heat transfer from a sphere suspended in a gas stream Flowing in a $1^{\prime \prime}$ diameter pipe.

$$
N u=2+\left[.4(R e)^{.6}+.06 R^{2 / 3}\right] \operatorname{Pr}^{.4}\left(\frac{M_{s+r e a n}}{M_{\text {mann }}}\right)
$$

Where he is the Reynolds number based on the sphere decimeter, Pr $=$ Brandt No. and $m=$ viscosity.

Assume Mstrean $=$ Moran

$$
\begin{aligned}
& R e=\frac{\varphi v d}{m_{i}}=\frac{\left(.0384 \frac{\mathrm{Lb}}{\mathrm{F}^{3}}\right)\left(.027 \frac{\mathrm{Ft}}{\mathrm{s}}\right)(.029 \mathrm{Ft})}{1.95 \times 10^{-5} 45 / 7+-5}=1.54 \\
& N n=2+\left[.4(1.54)^{1.5}+.06(1.54)^{2 / 3}\right](.68)^{.4}=2.49
\end{aligned}
$$

calculate heat transfer coefficient, h

$$
h=N_{u}\left(\frac{k}{d}\right)=2.49\left(\frac{.024 \frac{B+u}{h r-t+F}}{.029+t}\right)=2.06 \frac{B+n}{h r-F t^{2}-F}
$$

B-3

A-6nกก-482 to 1 tan! 
HNF-1506, Rev. 0

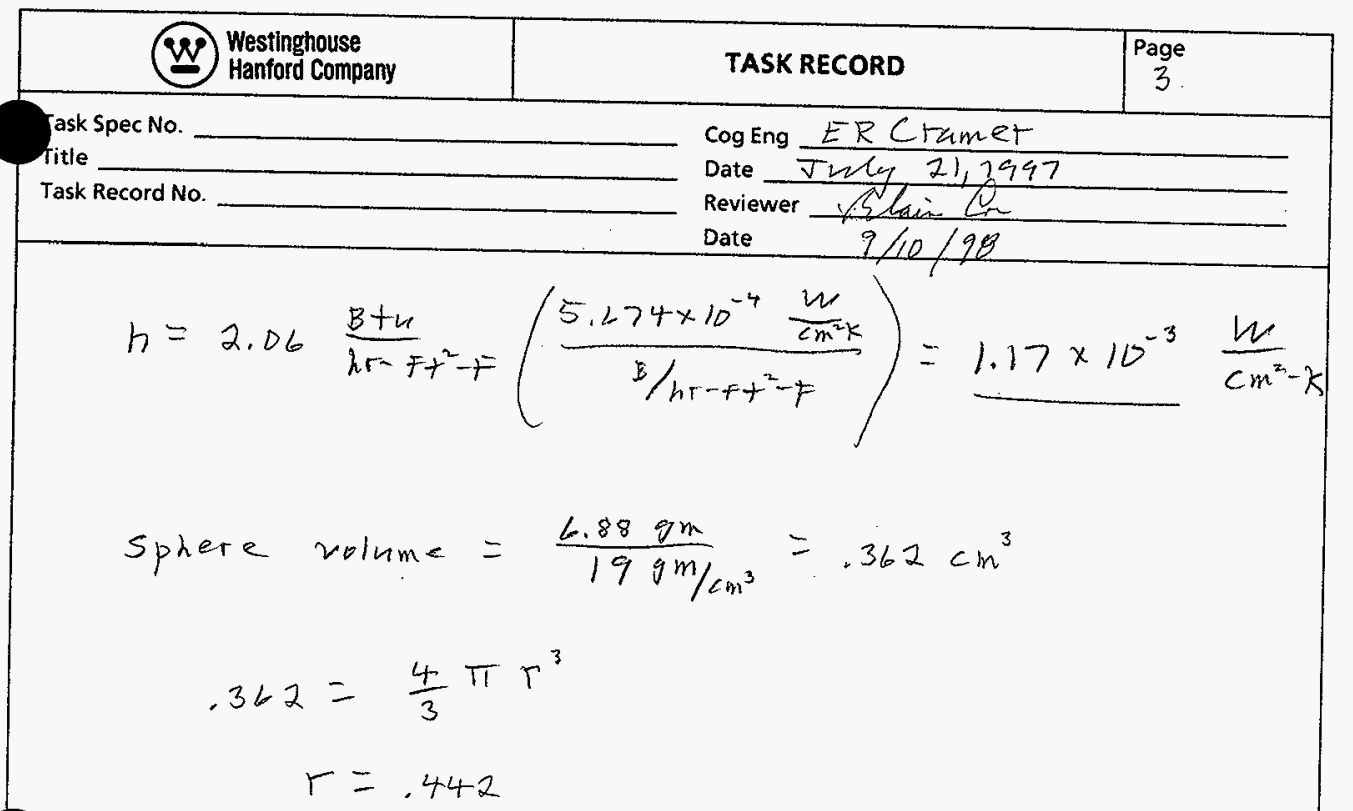

Sphere surface urea $=4 \pi r^{2}=2.457 \mathrm{~cm}^{2}$

Reaction Heat $\dot{q}=\frac{\Delta \omega}{t}\left(33.75 \frac{\mathrm{J}}{\mathrm{g}}\right)$

where $\Delta v=$ sample went quin, g

$t=t-i m e, \sec$

$$
\begin{aligned}
& \frac{\Delta W(33.75)}{t}=h A \Delta T \\
& \frac{\Delta W(33.75)}{t}=\left(1.17 \times 10^{-3} \frac{W}{\mathrm{~cm}^{2} \cdot \mathrm{k}}\right)\left(2.457 \mathrm{~cm}^{2}\right) \Delta T
\end{aligned}
$$

Solve this equation for $\Delta T$. Results wire given in Table 2. 
HNF-1506, Rev. 0

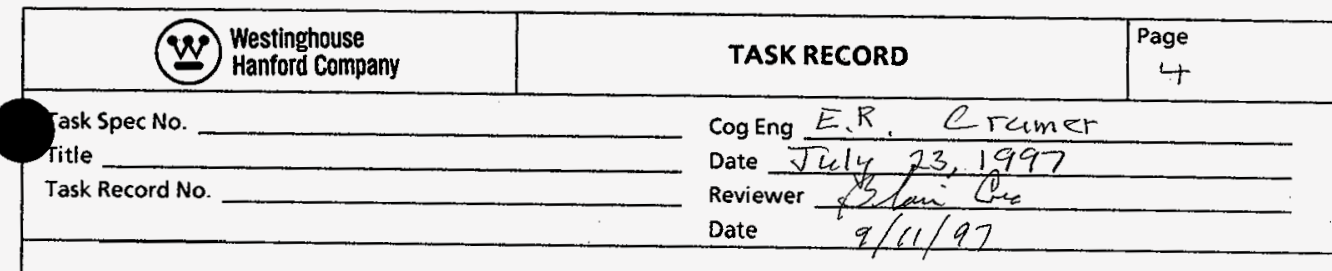

Calculate SNF temperature assuming convection and radiation from top surface and conduction from boHol surface through an ain yap.

$$
\begin{aligned}
& \dot{q}=\dot{q}_{\text {cons }}+\dot{q}_{\text {rad }}+\dot{q}_{\text {cons }}-E_{q u a t i o n} A \\
& \dot{q}=\text { reaction neat } \\
& \dot{q}_{\text {cons }}=\text { convection heat from top surface } \\
& \dot{q}_{\text {rad }}=\text { radiation heat from top surface } \\
& \dot{q}_{\text {lond }}=\text { conduction heat from bottom surface } \\
& \dot{q}=\frac{\Delta W}{t}\left(3.3(95) \times 10^{7} \frac{\mathrm{J}}{\mathrm{kg}}\right) \quad \text { - reaction neat }
\end{aligned}
$$

B-5

A. Gกกก.AR? in ian! 
HNF-1506, Rev. 0

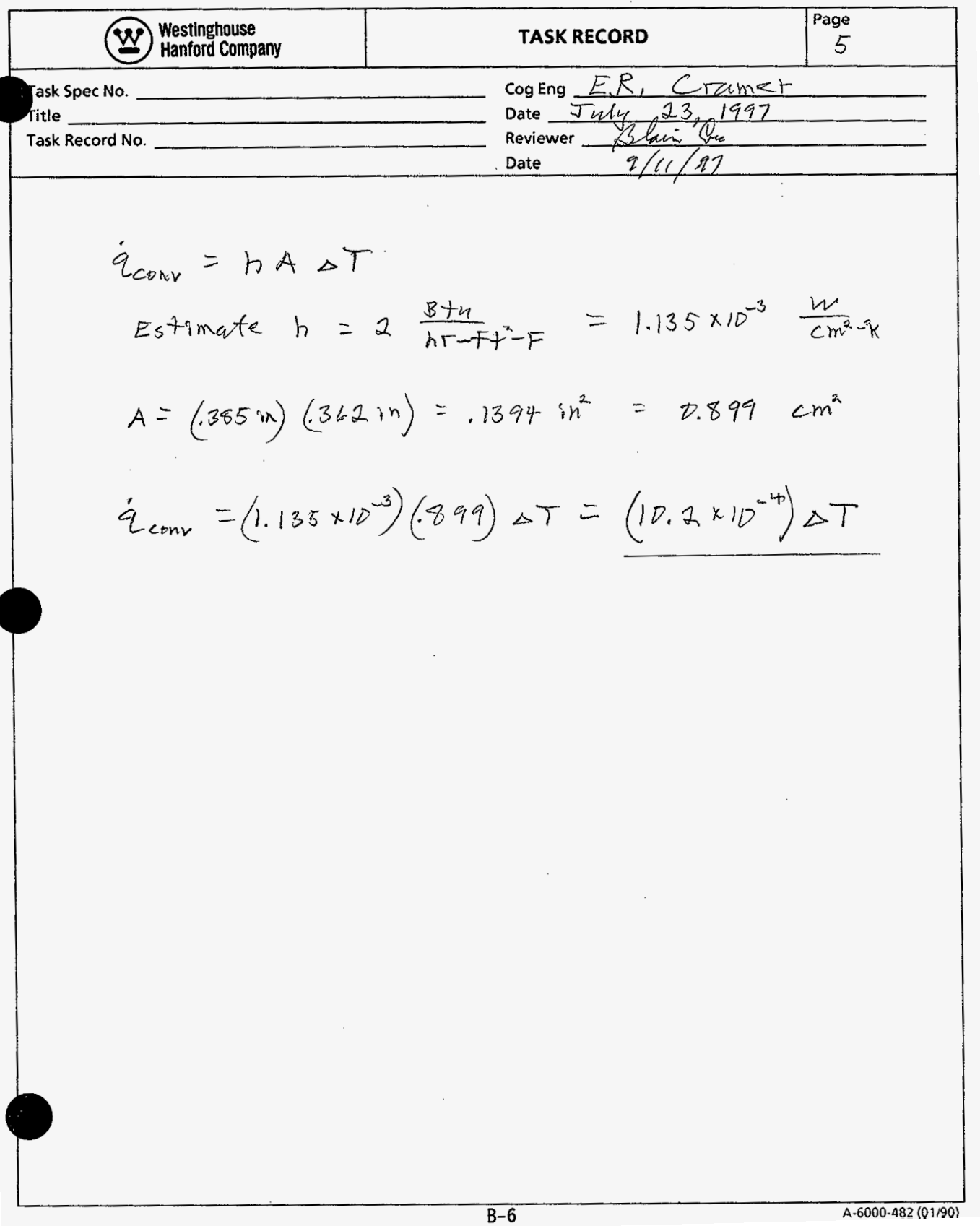


HNF-1506, Rev. 0

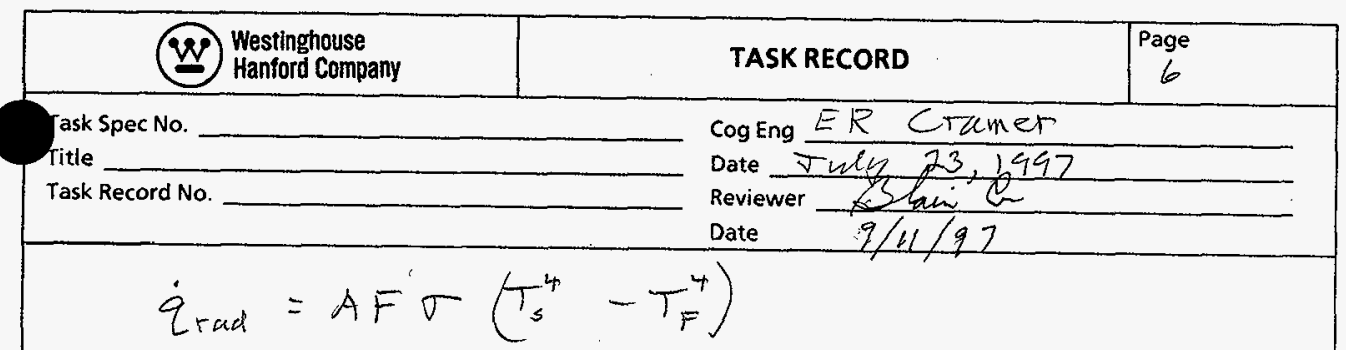

Assume view factor between furnace and sN sample is 1.0. Gray -body shape factor, $F$, is then:

$$
F=\frac{1}{\frac{1}{\epsilon_{1}}+\frac{1}{\epsilon_{2}}-1}
$$

graphite Furnace wall emissivity $\epsilon_{1}=0.98$ SNF sample emissivity $\epsilon_{2}=0.7$

$$
F=\frac{1}{\frac{1}{.98}+\frac{1}{.7}-1}=.69
$$

Stephan-B.1tzman constant $\sigma=5.6699 \times 10^{-12} \frac{\mathrm{m}}{\mathrm{cm}^{2}-\mathrm{k}^{4}}$

$$
\begin{aligned}
& A=.899 \mathrm{~cm}^{2} \\
& q_{\text {rad }}=.899(.69) 5.6699 \times 10^{-12}\left(T_{\text {SHF }}^{4}-T_{F}^{4}\right) \frac{\Delta T}{\Delta T} \\
& q_{\text {rad }}=\left[\frac{\left.3.517 \times 10^{-12}\left(T_{\text {serF }}^{4}-T_{F}^{4}\right)\right] \Delta T}{\Delta T}\right]
\end{aligned}
$$

where $T_{s}$ is Sal sample temperature and $T_{F}=$ is Furnace temperature

B-7

A- $6000-482(01 / 90)$ 
HNF-1506, Rev. 0

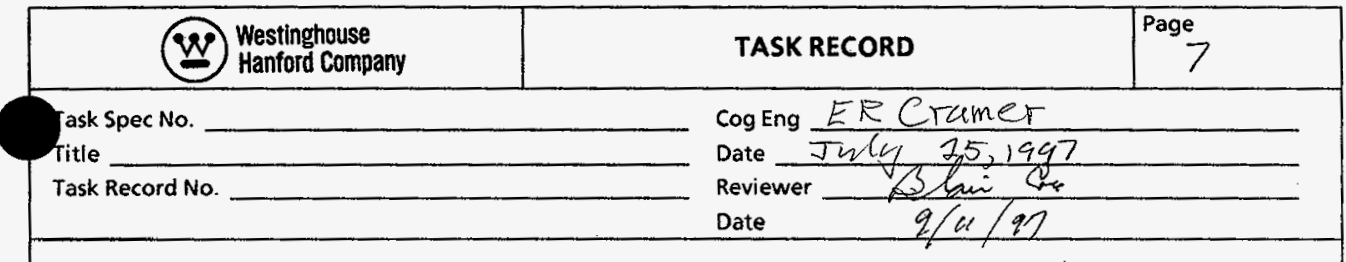

Air thermal conductivity, $K=4.15 \times 10^{-4} \frac{\mathrm{m}}{\mathrm{cm}-k}$

Assume length of heat transfer $p u+h=\frac{1}{2} \mathrm{~mm}=.05 \mathrm{c}$

Neglect resistance of quartz crucible

$$
\begin{aligned}
\dot{q}_{\text {cons }} & =\frac{k A}{d} \Delta T \\
\dot{q}_{\text {sand }} & =\frac{\left(4.15 \times 10^{-4}\right) \cdot 899}{.05} \Delta T \\
\dot{q}_{\text {cold }} & =\left(74.6 \times 10^{-4}\right) \Delta T .
\end{aligned}
$$

Substitute everything into Equation $A$

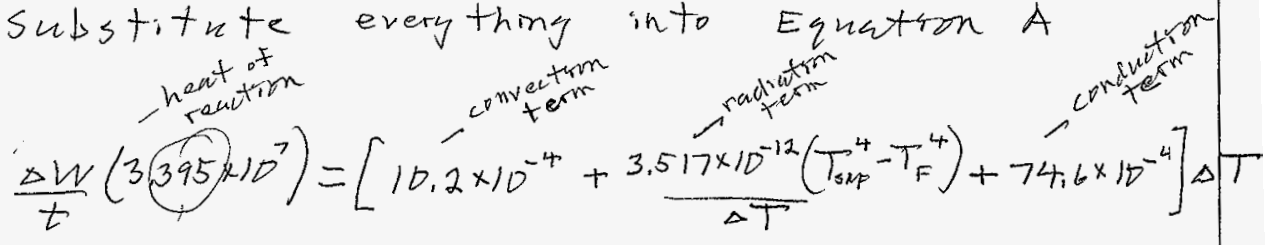

Temperature results cakedated by tic equation are given in Tulle 3.

sample weight gain, sw, and time, $t$ are also shown in Table 3.

B-8

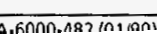


HNF-1506, Rev. 0

(2) Westinghouse

TASK RECORD

Page

ask Spec No.

Title

Task Record No.
Cog eng $E R$ Creamer

Date July 25,1997

Reviewer

Date

8

Now consider the heat loss through the contact area between the sN sample and the quartz crucible.

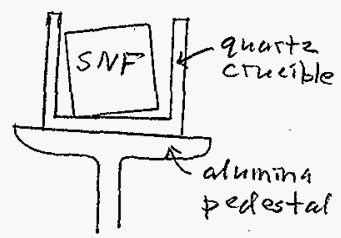

Assume 1\% of SNF area is in contact with quartz crucible

Heat transfer urea thru quartz:

$$
A=.01\left(.899 \mathrm{~cm}^{2}\right)=.00899 \mathrm{~cm}^{2}
$$

length through quartz $=(.015 \mathrm{in}) 2.54=.0381 \mathrm{~cm}$ quartz thermal cinauctirty:

$1 /$ to crystal axis, $k=.0527 \frac{\mathrm{m}}{\mathrm{cm}-k}$

$1+$ crystal axis, $k=.0353 \frac{m}{c m-k} \leftarrow \begin{aligned} & \text { use this } \\ & \text { cone to be } \\ & \text { conservative }\end{aligned}$

quartz condvetunce $u_{q}=\frac{k A}{l}=\frac{(.0353)(00890}{.0381}$

$$
u_{q}=.00833 \quad \frac{w}{\circ}
$$

B-9

A tran and ina ane 
HNF-1506, Rev. 0

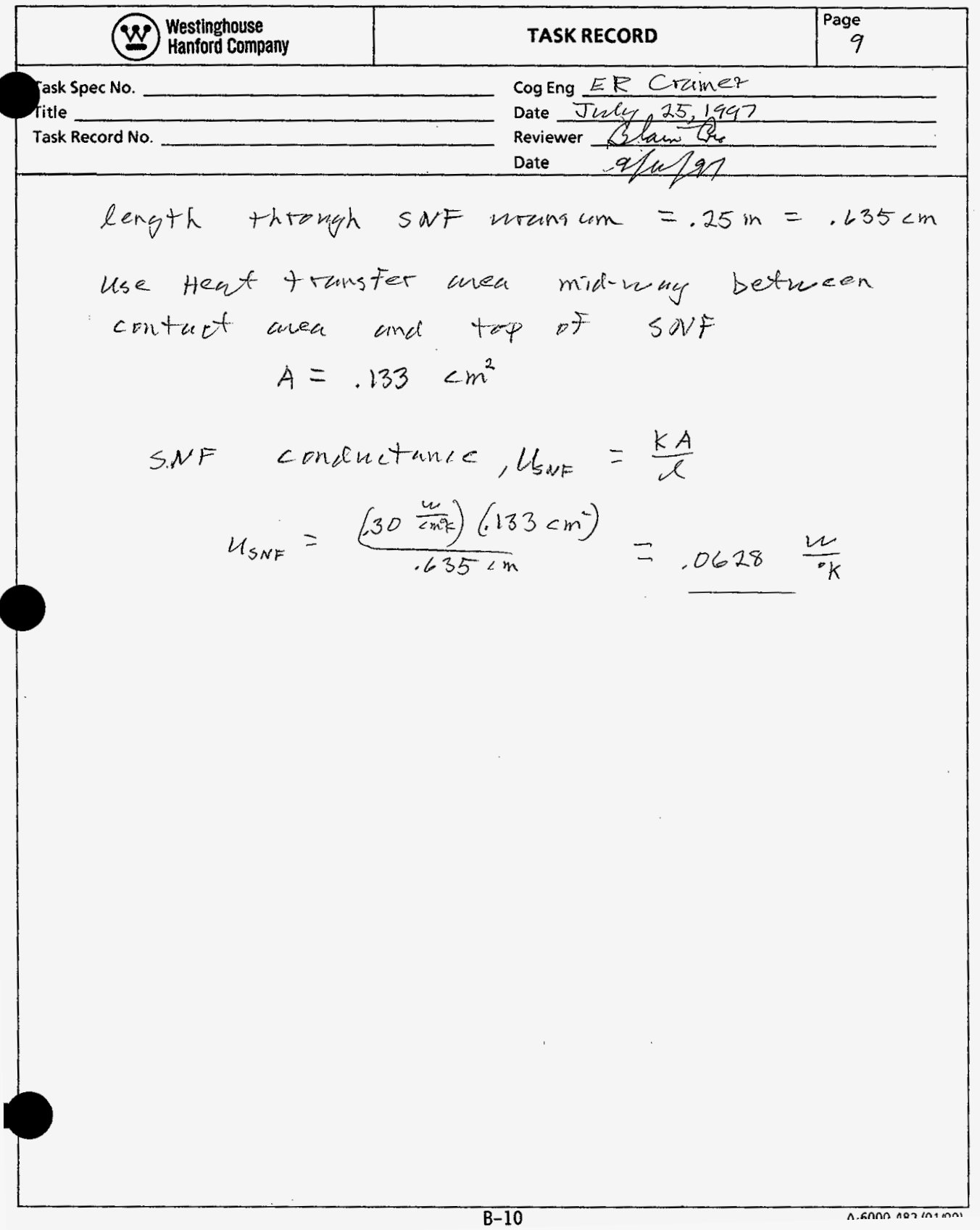


HNF-1506, Rev. 0

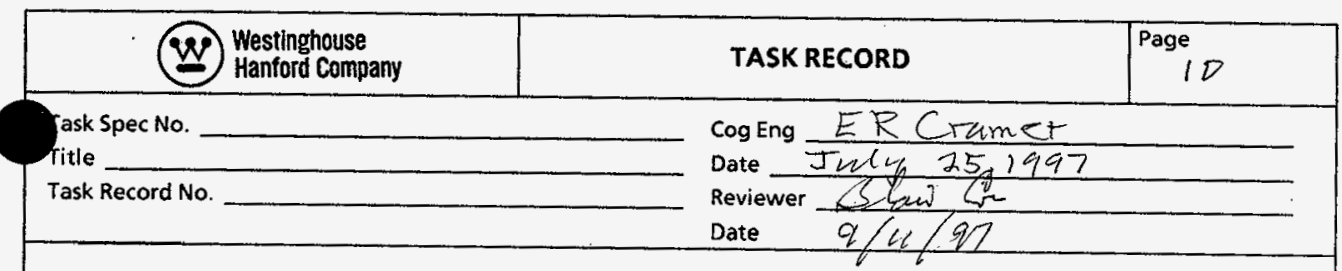

Alumina Pedestal Conductance

$l=.165 \mathrm{in}=.419 \mathrm{~cm}$ (ines is same as pedestal cia.)

use heat transfer area midenuy between quartz contact area and other side if alumina head

$A=.06 \mathrm{~cm}^{2}$

Alumina $u=\frac{k A}{\mu}=\frac{\left(17 \frac{w}{c m-k}\right)\left(.066 \mathrm{~cm}^{2}\right)}{.419 \mathrm{~cm}}=.0268 \frac{w}{r k}$

calculate overall conductance, 4

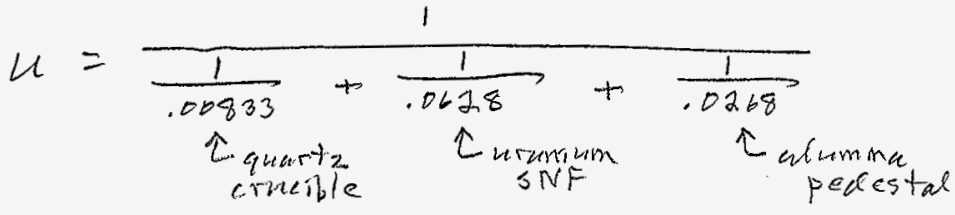

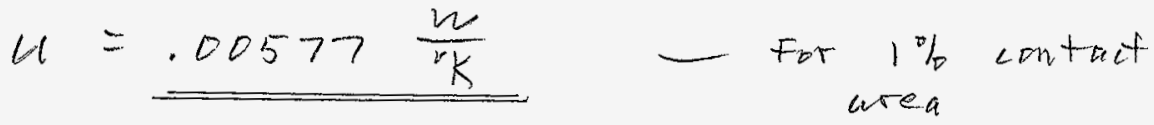

$$
\begin{aligned}
& u=.0577 \frac{m}{K} \text { - for } 10 \% \text { contact woe }
\end{aligned}
$$

B-11 
HNF-1506, Rev. 0

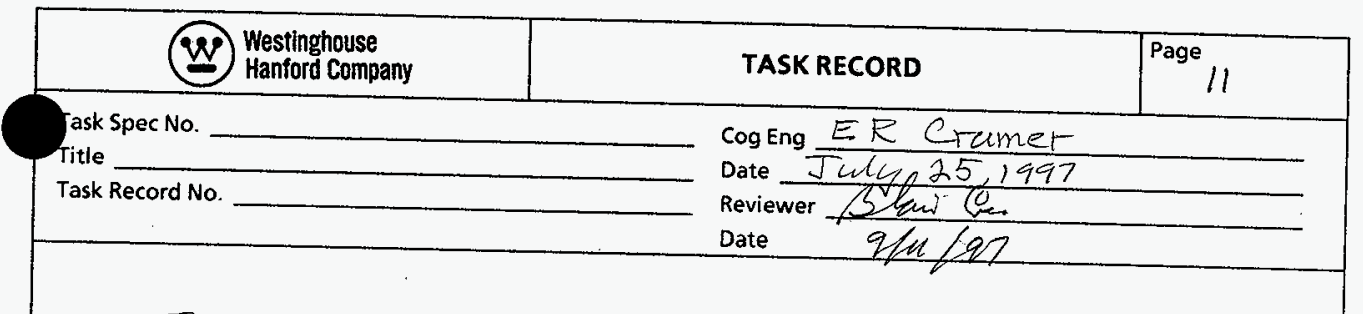

For analysis of $1 \%$ or $10 \%$ contact urea, add the above conductance term to equation $A$ :

$$
\begin{aligned}
& \dot{q}=\dot{q}_{\text {cons }}+\dot{q}_{\text {rad }}+\dot{q}_{\text {conc }}+\dot{q}_{\text {contact }} \\
& \frac{\Delta W\left(3.395 \times 10^{7}\right)}{t}=5 \\
& {\left[10.2 \times 10^{-4}+\frac{3.517 \times 10^{-12}\left(T_{\text {sN }}^{4}-T_{F}^{4}\right)}{\Delta T}+74.6 \times 10^{-4}+u\right] \Delta T}
\end{aligned}
$$

Temperature results calculated by this equation are given in Table 4 for $1 \%$ contact area, and Table 5 for $10 \%$ contact area. 
HNF-1506, Rev. 0

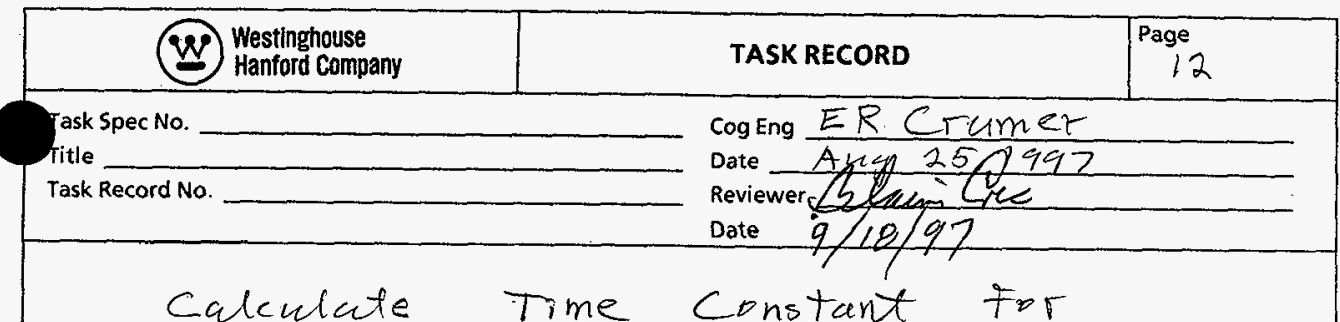

Calculate Time Constant For thermocouple response to step change in surface temperature of SNF sample.

Assume lumper neat unpucitay system.

Time constant $r=\frac{\rho V C_{p}}{h A}$

$$
\begin{aligned}
& \rho=\text { amino density } \\
& V=\text { uranium volume }
\end{aligned}
$$

$c_{p}=$ uranium heat capacity

$h=$ heat transfer coefficient from uranium surface to thermocouple

$A=$ neat transfer area

sample thickness $=0.25$ inch

$$
\begin{aligned}
& V=\frac{(25 i n) A}{12 \text { int }+4}=.02083 \mathrm{~A} \\
& P=1167^{1 b} / F t^{3} \\
& c_{p}=.031 \frac{B+4}{1 b-F}
\end{aligned}
$$

B-13

A.6กnก- $\triangle 82$ the 
HNF-1506, Rev. 0

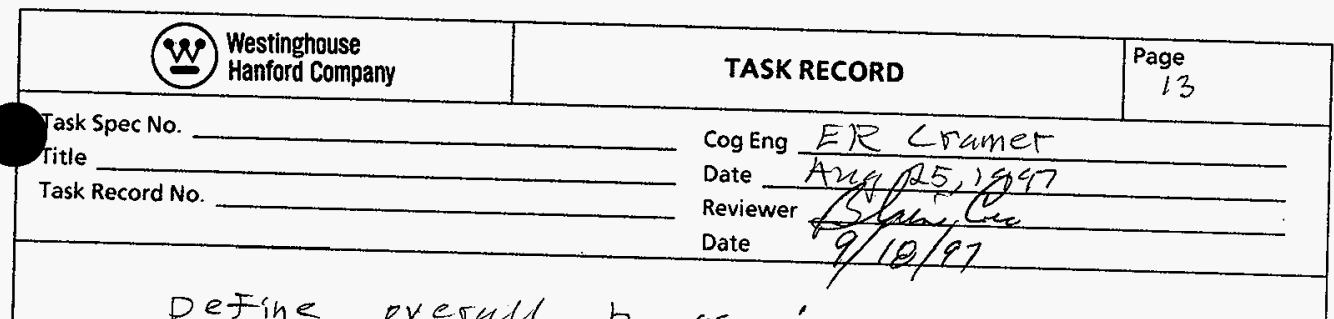

Define overall $h$ as:

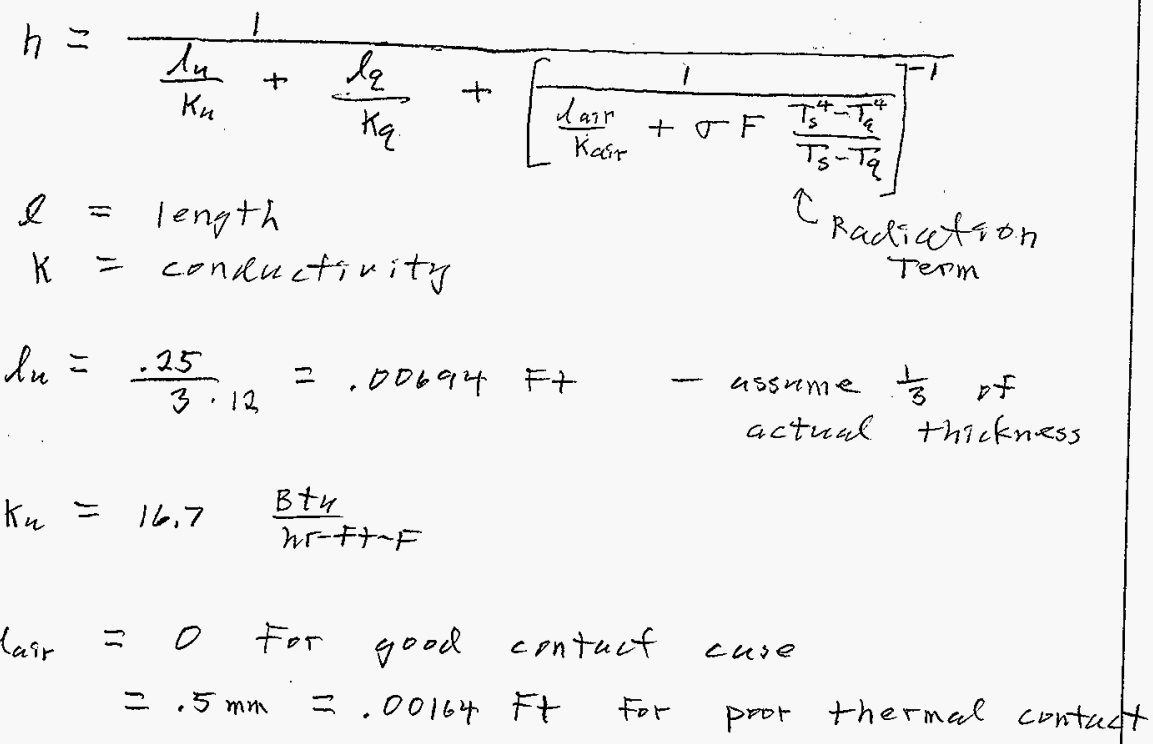

$$
\begin{aligned}
& K_{\text {ait }}=.022 \frac{B+u}{n+F+F} \\
& l_{q}=.02 \mathrm{in}=.00167 \mathrm{Ft} \quad \text { thickness of } \\
& \text { quartz eruoble } \\
& K_{q}=2.89 \frac{B+h}{h r-F+-F}
\end{aligned}
$$

$B-14$ 


$$
\text { HNF-1506, Rev. } 0
$$

(W) Westinghouse

Task Spec No.

Title

Task Record No.
TASK RECORD

Cog eng ER Cramet

Date Any, 25, 1990

Reviewer Stress

Date $q / 18 / 97$

$$
\begin{aligned}
\sigma=.1714 \times 10^{-8} & \frac{B+n}{n r \cdot F t^{2}-F^{-3}} \text { - stephan } \\
=\frac{1}{\frac{1}{\epsilon_{q}}+\frac{1}{\epsilon_{n}}-1} & =\frac{1}{\frac{1}{5}+\frac{1}{7}-1}=.41 \\
\text { where } \epsilon_{q} & =\text { quartz emissivity } \\
\epsilon_{n} & =\text { uranium emissivity }
\end{aligned}
$$

For the radiation term, assume

$$
\begin{aligned}
& T_{s}=575{ }^{\circ} \mathrm{F}=1035{ }^{\circ} \mathrm{R} \\
& \left.T_{q}=572 \% \text { (300 }=1032{ }^{\circ} \mathrm{K}\right)
\end{aligned}
$$

For good thermal contact, the surfaces are in contact so there is no radiation term and no air term.

B-15

A- $6000-482(01 / 90)$ 
HNF-1506, Rev. 0

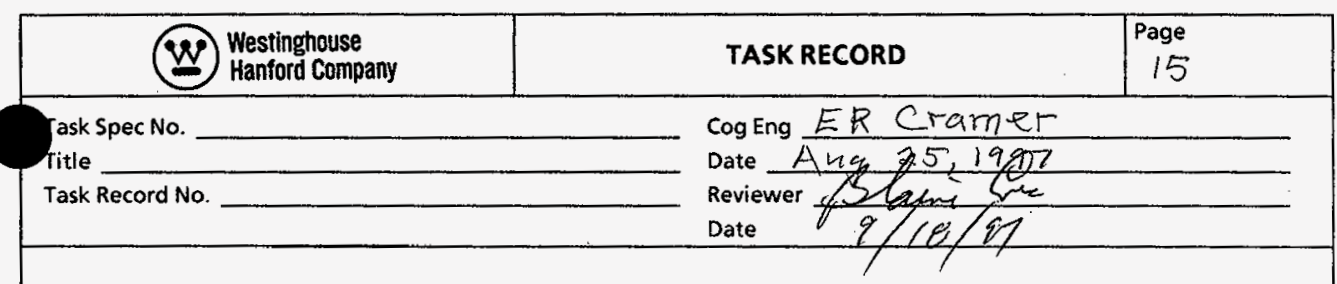

For good thermal contact case:

$$
\begin{gathered}
h=\frac{1}{\frac{.00694}{16.7}+\frac{.00167}{2.89}}=1007 \frac{B+4}{h+-F t^{2}-F} \\
\tau=\frac{\left(11 k 7 \frac{16}{F+3}\right)(.02083 F t) A\left(.031 \frac{B+n}{16 . F}\right)\left(3600 \frac{5}{h t}\right)}{\left(1007 \frac{B 4 n}{h r-f t^{2}-F}\right) A} \\
\tau=2.7 \text { seconds }
\end{gathered}
$$

B-16

A. $6000-482(01 / 90)$ 
HNF-1506, Rev. 0

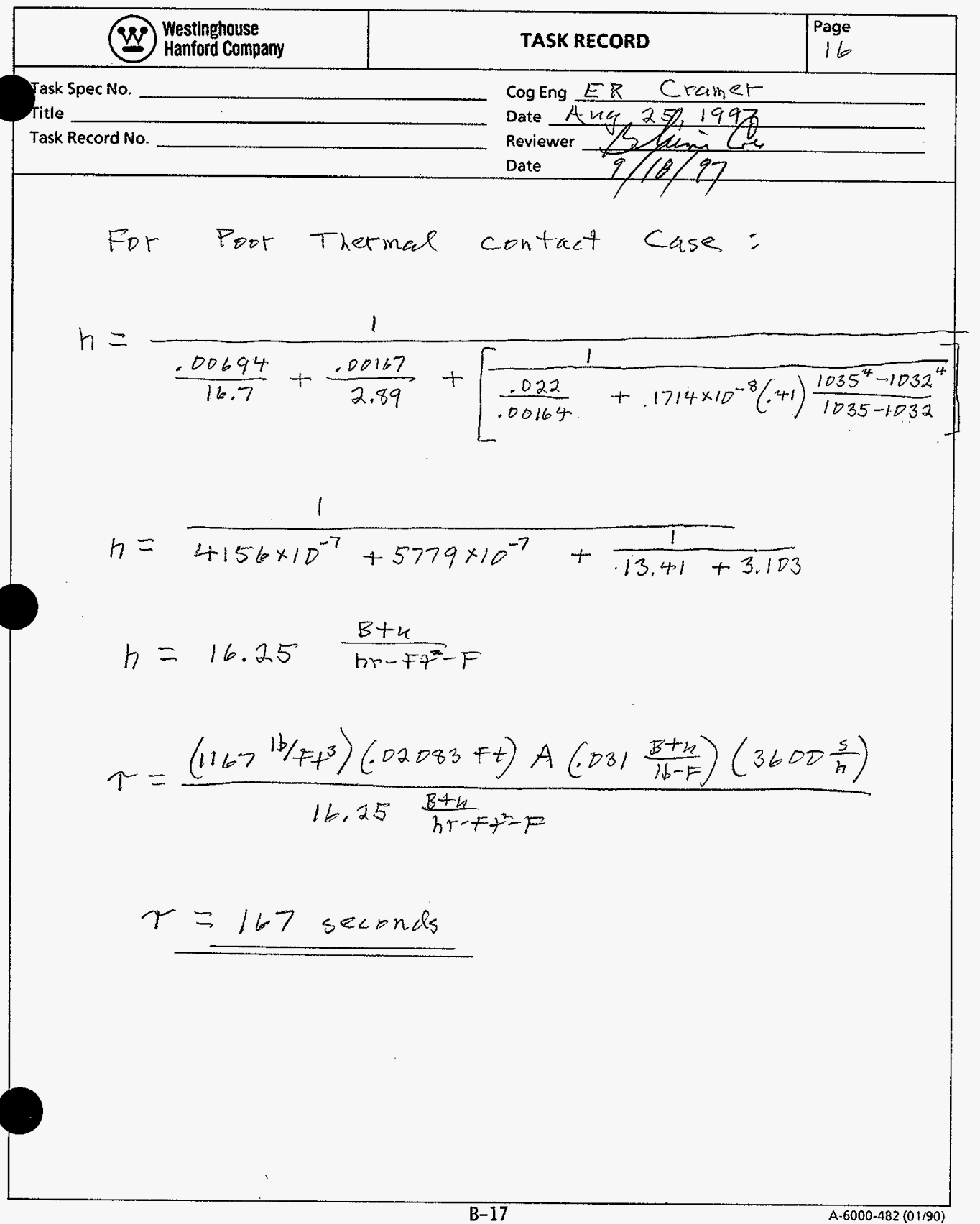




\section{DISTRIBUTION SHEET}

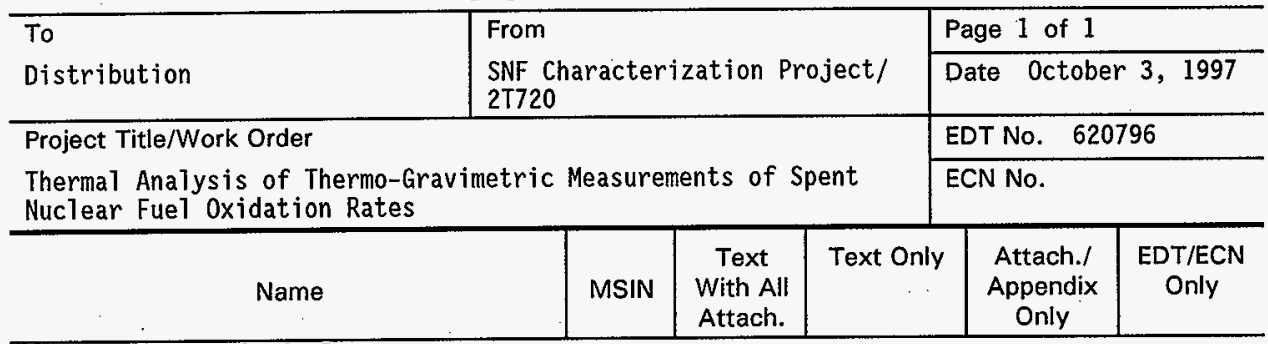

F]uor Daniel Hanford, Inc.

E. W. Gerber

R3-11 $\quad X$

Duke Engineering \& Services Hanford, Inc.

R. B. Baker

J. R. Frederickson

F. G. Hudson

L. A. Lawrence

(5)

B. J. Makenas

R. P. Omberg

D. W. Smith

J. A. Swenson

D. J. Trimble

SNF Project Files

Central Files

$\begin{array}{ll}H 0-40 & X \\ \text { R3-86 } & X \\ \text { R3-11 } & X \\ H 0-40 & X \\ H 0-40 & X \\ H 0-40 & X \\ \text { R3-15 } & X \\ \text { R3-11 } & X \\ \text { H0-40 } & X \\ \text { R3-11 } & X \\ \text { A3-88-BI-D7 } & X\end{array}$

Lockheed Martin Hanford Corp.

J. J. Irwin

HO-34 X

Numatec Hanford Corporation

E. R. Cramer

T. A. Flament

C. R. Miska

J. P. Sloughter

HO-34 $\quad X$

K9-46 $\quad X$

R3-86 $\quad x$

Pacific Northwest National Laboratory

J. Abrefah (2)

S. C. Marschman

U.S. Department of Energy,

Richland Operations office
P. G. Loscoe
E. D. Sellers
J. Shuen

P7-27

P7-27

$x$
$x$

S7-41

$57-41$

S7-41
$X$
$X$
$X$ 